\title{
DRÓN ALAPÚ LAST-MILE LOGISZTIKA JÁRATTERVEZÉSI FELADATAINAK MEGOLDÁSA
}

\author{
Francuz Ádám \\ hallgató, Miskolci Egyetem, Gépészmérnöki- és Informatikai Kar \\ 3515 Miskolc, Miskolc-Egyetemváros, e-mail: francuzadam13@gmail.com \\ Bányai Tamás \\ egyetemi docens, Miskolci Egyetem, Logisztikai Intézet \\ 3515 Miskolc, Miskolc-Egyetemváros, e-mail: alttamas@uni-miskolc.hu
}

\begin{abstract}
Absztrakt
Az online vásárlás és e-kereskedelem egyre jelentősebb elterjedése számos kihívást eredményez, a folyamatosan növekvö csomagszállitási igények megvalósitására új megoldások jelentek meg a last-mile logisztikában. A drón alapú last-mile logisztikai folyamatok napjainkban föként teszt fázisban vannak, azonban már több multinacionális szállitmányozási vállalat birtokol légi engedélyt ezen drónok használatára. Jelen cikk keretében a szerzök egy olyan megoldási algoritmust mutatnak be, mely alkalmas a drón alapú last-mile járattervezési feladatok megoldására.
\end{abstract}

Kulcsszavak: drón, last-mile logisztika, járattervezés, optimalizálás, modellezés

\section{Abstract}

The increasing growth of online shopping and e-commerce is creating several challenges, and new solutions have emerged in last-mile logistics to meet the ever-increasing demand for parcel delivery. Drone-based last-mile logistics processes are nowadays mainly in the testing phase, but several multinational freight forwarding companies already have air licences to use these drones. Within the frame of this article the authors present a solution algorithm suitable for solving drone-based last-mile flight planning tasks.

Keywords: drone, last-mile logistics, routing, optimization, modelling

\section{Bevezetés}

A folyamatosan fejlődő és diverzifikálódó vevői igények teljes mértékben átalakítják a különböző logisztikai szolgáltatások müködését, köztük a last-mile logisztikai folyamatokat is. Az e-kereskedelem és online vásárlás világában egyre nagyobb jelentőségre tesz szert a házhozszállítási logisztikai folyamatok fejlesztése és optimalizálása. A globális kereskedelemben számos konkurens vállalat kínál jobbnál jobb lehetőségeket, amelyek rugalmasan tudnak reagálni a vevői igények folyamatos változásaira. A negyedik ipari forradalom és a digitális technológia fejlődésével a drónokkal történő szállítási mód kezd egyre inkább feltörekedni. Ez a fajta megoldás évekkel ezelőtt csak távoli elképzelésként jöhetett volna szóba, viszont napjainkban már több szállítmányozási cég birtokol hivatalos engedélyt a drónokkal történő csomagszállítás megvalósítására. A drónokkal történő szállítás megoldást kínálhat a környezetvédelmi, illetve akár a munkaerőhiány kiküszöbölésére is.

Jelen tudományos cikkben megvizsgáljuk a különböző drón alapú last-mile logisztika megoldási módszereit, különböző előnyeit és feltételeit, valamint kitérünk a drón alapú szállítás körutazásként történő megvalósítására. A körutazást a logisztikai optimalizálás során gyakran alkalmazott Branch \& Bound algoritmus segítségével hajtjuk végre. A körutazás végeredményét összehasonlítjuk az ingajárat 
útvonalával, amely rámutat, milyen fontos ezen tudományterülettel foglalkozni és megoldást találni ezek megvalósítására.

\section{Drón alapú szállítás előnyei}

A közúti szállítással ellentétben a drónok légvonalban közlekedhetnek, ami lehetővé teszi számukra, hogy elkerüljék a forgalmat és a bonyolult navigációs útvonalakat. A szállítási mód kiválasztásának során a gyorsaság fontos érv a vásárlók számára. Egy kutatás szerint a vásárlók 79\%-a szívesen választaná a drónos kiszállítást, ha a csomagját rövidebb időn belül ki tudnák szállítani (Walker, 2016). Ráadásul a gyorsabb szállítási idő potenciálisan csökkentheti a vásárlók szállítási költségeit, ez pedig a kiskereskedők számára forgalomnövekedést eredményezhet. Továbbá fontos kiemelni, hogy ez a technológia a meglévő szállítási módszerekkel együtt müködhetne az áruk gyorsabb és költséghatékonyabb teljesítésének elősegítése érdekében (Delivery, 2021).

A számos gazdasági előnyök mellett a drónok felhasználásának környezetvédelmi előnyei is vannak. Egy csomag közúti kiszállítása körülbelül $1 \mathrm{~kg}$ üvegházhatású gázkibocsátást eredményez. A Nature Communications című szaklapban 2018-ban megjelent tanulmányból kiderült, hogy a dízelüzemü kézbesítő teherautók helyett kisméretű drónok használata az energiafogyasztás, valamint az üvegházhatású gázok kibocsátásának csökkentése révén segíthet az éghajlatváltozás elleni küzdelemben (Nature, 2018). A drónos szállításnak vannak hátrányai is: a légtér használata során veszélyeztetheti más objektumok illetve a légtér alatt közlekedők biztonságát, a drónok szakszerü kezelése nagy gyakorlatot igényel, biztosítási problémák.

\section{Szakirodalmi áttekintés}

A nemzetközi szakirodalom számos paraméterében egyetért a drón alapú szállítási lehetőségek alkalmazásával kapcsolatban. Kialakulásának oka az e-kereskedelem révén növekvő fogyasztói kereslet és a vevői elvárások. Ennek érdekében a vállalatok költséghatékony és gyorsabb szállítási müveletekre törekszenek. Az autonóm jármüvek, köztük a drónok integrálása a last-mile logisztikai feladatok ellátására jelentős versenyelőnyt biztosíthat a konkurens vállalatokkal szemben (Salama, 2020), ezáltal az a drón alapú logisztikai modellek operatív tervezése az elmúlt években jelentős növekedésre tett szert (Moshref-Javadi, 2021). Az Ipar 4.0 új logisztikai berendezések és új logisztikai megoldások müködtetését teszi lehetővé, amelyek kiber-fizikai rendszereken alapulnak.

A drónokkal történő szállítás visszavezethető a szakirodalomban jól ismert utazóügynök problémára (angolul: Travelling Salesman Problem, TSP), így számos cikkben „TSP-D” (Drone based Travelling Salesman Problem) kifejezésként hivatkoznak rá, amelynek célja a teljes szállítási idő minimalizálása. Mivel a probléma legtöbb változata NP-nehéz, metaheurisztikán alapuló megközelítéssel lehet optimális megoldást találni, amely megvalósítására számos algoritmus áll rendelkezésre.

A metaheurisztikán alapuló adaptív és intelligens algoritmusok, amelyek számos hasonló problémánál bizonyították sikerüket. Konstrukciós körút algoritmusok közül kiemelhető a „legközelebbi szomszéd algoritmus" (angolul: Nearest neighbour algorithm), míg javító algoritmusok közül a genetikai algoritmus (Agárdi, 2020). Randomizált adaptív keresési eljárásként a Mohó algoritmus lokális keresési alternatívákkal választja ki az optimális eredményt (Almuhaideb, 2021). A probléma kiterjeszthető a járattervezési problémára (angolul: Vehicle Routing Problem, VRP), amely a szállítási útvonal minimalizálása mellett a szállítás ütemezésének optimalizálására is kitér. A különböző algoritmusokkal kapott eredményeket az út-, és költségparaméter szerint lehet összehasonlítani (Yadav, 2018). 


\section{Matematikai modell}

A drónokkal történő szállítás körutazási feladatnak tekinthető. A körutazási feladat két fontos eleme, hogy a kiindulási és érkezési pont egyezzen meg, valamint az útvonalat alkotó állomások kizárólag egyszer legyenek az útvonal részei. A feladat matematikai módon sokféle módon értelmezhető és számos megoldási módszer alakult ki ezen körútvonalak optimalizálására. Az útvonal felfogható egy teljes, súlyozott gráfként $(\mathrm{G})$, ahol a gráf csúcsai az állomáspontok (A, B, C, ..), az élek pedig a pontokat összekötő szakaszának hosszát jelölik. Ezt a speciális gráfot Hamilton-útnak nevezzük. Ha Hamilton-út gráfot kiterjesztjük azzal a paraméterrel, hogy a kezdő és végpont egyezzen meg, akkor Hamilton-körről beszélünk (1. ábra).
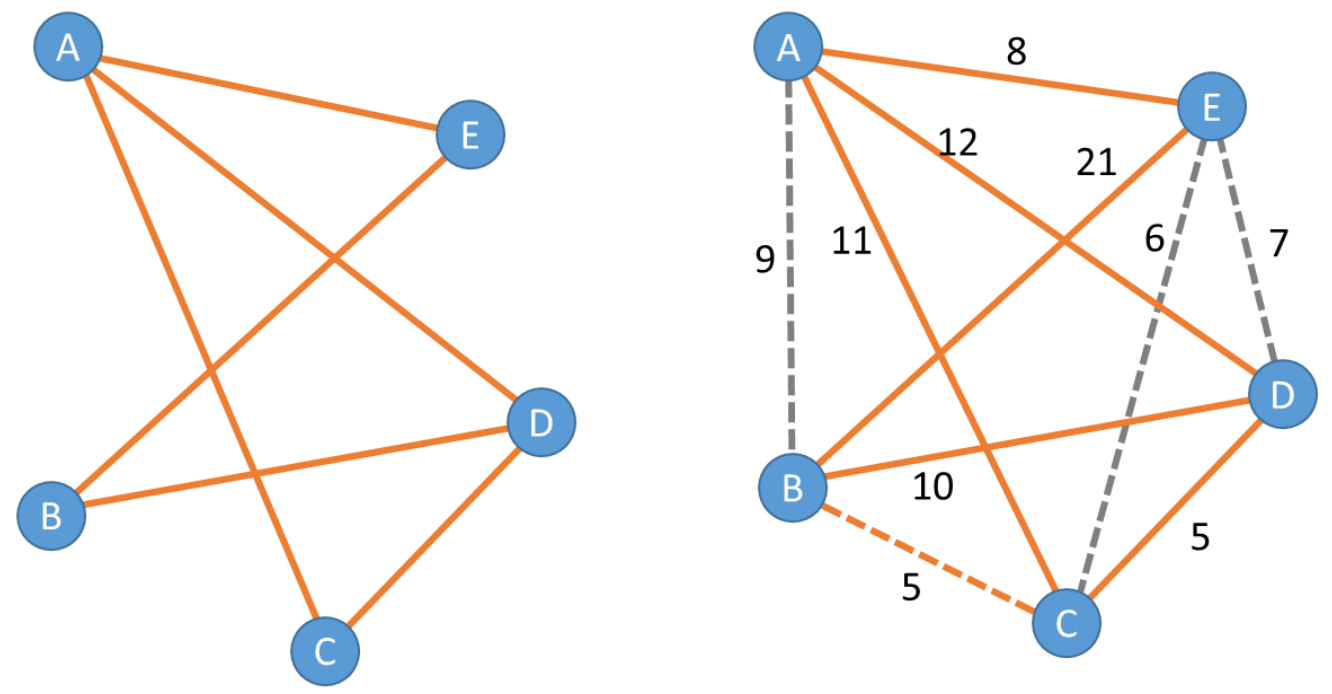

1. ábra TSP alkalmazása, mint Hamilton-kör (saját szerkesztés)

Az utazóügynök problémája felírható, mint egy egészértékủ lineáris programozási feladat. A városokat 1 ...n-ig jelöljük el. Az $x_{i j}$ paraméter egy bináris érték, megadja, hogy az i-edik és j-edik város között van-e valós útszakasz:

$$
x_{i j}=\left\{\begin{array}{cc}
\mathbf{1}, & \text { ha i és j közötti útszakasz benne van a Hamilton }- \text { körben } \\
\mathbf{0}, & \text { ha i és j közötti útszakasz nincs benne a Hamilton - körben }
\end{array}\right.
$$

A $D_{i j}$ paraméter megadja az i és közötti útszakasz hosszát. A feladat célfüggvénye felírható ezekkel a paraméterekkel:

$$
\begin{gathered}
\sum_{i=0}^{n} \sum_{j=0}^{n} D_{i j} * x_{i j} \rightarrow \min \\
i=1 \ldots n \\
j=1 \ldots n
\end{gathered}
$$

A célfüggvény összeadja azokat a távolságokat, amelyek szerepelnek a Hamilton-körbe. A feladat célja ezen összeg út paraméter szerinti optimalizálása. A célfüggvény korlátozásai:

1. Minden i pontot elhagyunk pontosan egyszer: 


$$
\sum_{j=1}^{n} x_{i j}=1
$$

2. Minden j pontba beérkezünk pontosan egyszer:

$$
\sum_{i=1}^{n} x_{i j}=1
$$

3. A kiindulási és érkezési pont („,k” pont) megegyezik:

$$
\sum_{j=0}^{n} x_{0 j}=\sum_{i=0}^{n} x_{i 0}=k
$$

\section{Utazóügynök probléma megoldási módszerei}

A TSP feladat megoldására számos módszer létezik. NP-nehéz feladatról van szó, tehát a feladat teljes megoldásterének vizsgálata nem célravezető. Hagyományos megoldásnak tekinthető a „Nyers erő” algoritmus (angolul: Brute Force), amely egy egymásba illesztett lineáris keresés, de ez csak korlátozott számú állomásra alkalmazható. Véltelen választáson alapuló algoritmusként kiemelhető az Evolúciós (genetikus) algoritmus, a Hangyakolónia algoritmus, Tabu keresés vagy Szimulált hűtés algoritmusa. Az egyik leggyakrabban használt megoldási módszer a kombinatorikus optimalizálási feladatok megvalósítására a Branch \& Bound algoritmus, vagyis a korlátozás és szétválasztás módszere. Dolgozatomban ezt a módszert fogom alkalmazni az optimalizált körúttervezés megvalósítására. A módszer során n állomás esetén (n-1)! megoldás jöhet szóba. Az összes lehetőség megvizsgálására nincs lehetőség, mert például 10 állomás esetén $9 !=362.880$ lehetőség jöhet szóba, az pedig nagyon időigényes megoldás. A módszer célja, hogy különböző részfeladatokra bontja a teljes megoldási halmazt, és megpróbál minél több megoldási irányt elzárni, ezzel csökkentve a lehetséges megoldások számát. A lehetséges megoldásokat faszerkezetben írjuk fel (2. ábra).

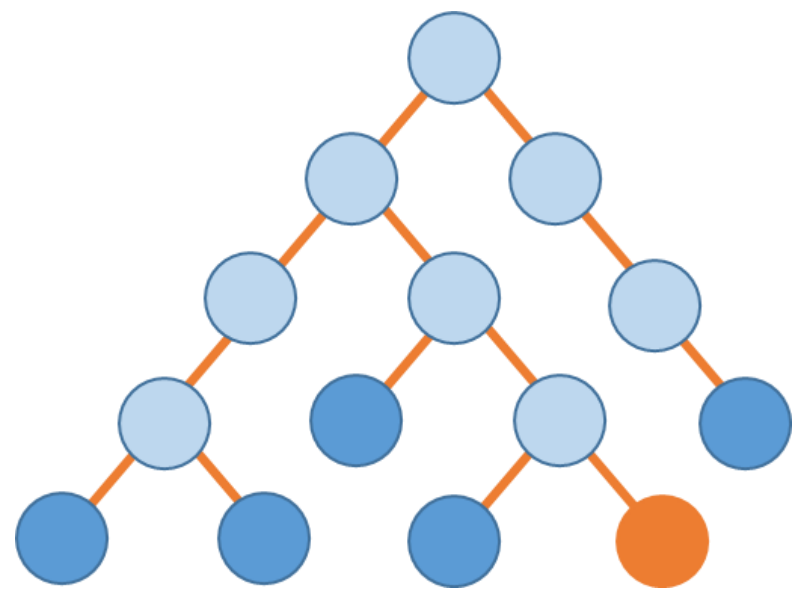

2. ábra Branch \& Bound algoritmus faszerkezete (saját szerkesztés)

A „szétválasztás” kifejezés utal arra, hogy az egészértékủ programozási feladatot részfeladatokra bontjuk úgy, hogy azok célfüggvénye megegyezzen a programozási feladat célfüggvényével, a lehetséges megoldások halmaza pedig részhalmaza legyen a feladat megoldási halmazának. A „korlátozás” kifejezés azt jelenti, hogy a részfeladatok optimális célfüggvényértékére lazítási korlátok kerülnek meghatározásra, amik segítségével számos részfeladatot lehet kizárni. 


\section{Megoldási algoritmus bemutatása}

A feladat kiindulási adata egy 10 állomást tartalmazó útmátrix, amely tartalmazza az állomások közötti szakasztávolságot. Célunk egy olyan körútvonalat létrehozni, amely a „1” jelü állomásból indul ki és érkezik vissza, a bejárás során pedig minden állomást pontosan egyszer érint (3. ábra).

\begin{tabular}{|c|c|c|c|c|c|c|c|c|c|c|c|}
\hline$\Delta$ & A & $B$ & $C$ & $\mathrm{D}$ & $E$ & $\mathrm{~F}$ & G & $\mathrm{H}$ & 1 & $\mathrm{~J}$ & K \\
\hline 1 & $\mathrm{R}$ & 1 & 2 & 3 & 4 & 5 & 6 & 7 & 8 & 9 & 10 \\
\hline 2 & 1 & $\mathbf{x}$ & 11 & 12 & 15 & 18 & 11 & 12 & 6 & 10 & 1 \\
\hline 3 & 2 & 14 & $\mathbf{x}$ & 8 & 14 & 1 & 5 & 11 & 7 & 16 & 8 \\
\hline 4 & 3 & 20 & 6 & $\mathbf{x}$ & 10 & 4 & 10 & 5 & 11 & 14 & 10 \\
\hline 5 & 4 & 19 & 10 & 18 & $\mathbf{x}$ & 5 & 10 & 7 & 2 & 11 & 8 \\
\hline 6 & 5 & 8 & 18 & 16 & 9 & $\mathbf{x}$ & 6 & 3 & 5 & 11 & 2 \\
\hline 7 & 6 & 19 & 9 & 18 & 1 & 7 & $\mathrm{x}$ & 17 & 11 & 13 & 20 \\
\hline 8 & 7 & 12 & 15 & 16 & 4 & 20 & 16 & $\mathbf{x}$ & 4 & 18 & 18 \\
\hline 9 & 8 & 11 & 8 & 6 & 17 & 18 & 8 & 8 & $\mathbf{x}$ & 19 & 19 \\
\hline 10 & 9 & 3 & 9 & 19 & 7 & 18 & 15 & 12 & 19 & $\mathbf{x}$ & 20 \\
\hline 11 & 10 & 1 & 12 & 5 & 16 & 4 & 13 & 6 & 18 & 3 & $\mathbf{x}$ \\
\hline
\end{tabular}

3. ábra Kiindulási útmátrix (saját szerkesztés)

Az algoritmus első lépése a redukált mátrix létrehozása (4. ábra). A redukált mátrix egy olyan, a kiindulási útmátrixból kapott mátrix, amely minden sorában és oszlopában legalább egy „,0 érték található, melyet úgy érünk el, hogy minden sor és oszlop minimális értékét kivonjuk az adott sor vagy oszlop összes értékéből. Ezen minimális értékek összege a további számítások során fontos szerepet tölt be.

\begin{tabular}{|c|c|c|c|c|c|c|c|c|c|c|}
\hline $\mathrm{R}$ & 1 & 2 & 3 & 4 & 5 & 6 & 7 & 8 & 9 & 10 \\
\hline 1 & $\mathbf{x}$ & 8 & 11 & 14 & 17 & 8 & 10 & 5 & 7 & 0 \\
\hline 2 & 13 & $\mathbf{x}$ & 7 & 13 & 0 & 2 & 9 & 6 & 13 & 7 \\
\hline 3 & 16 & 0 & $\mathbf{x}$ & 6 & 0 & 4 & 0 & 7 & 8 & 6 \\
\hline 4 & 17 & 6 & 16 & $\mathbf{x}$ & 3 & 6 & 4 & 0 & 7 & 6 \\
\hline 5 & 6 & 14 & 14 & 7 & $\mathbf{x}$ & 2 & 0 & 3 & 7 & 0 \\
\hline 6 & 18 & 6 & 17 & 0 & 6 & $\mathbf{x}$ & 15 & 10 & 10 & 19 \\
\hline 7 & 8 & 9 & 12 & 0 & 16 & 10 & $\mathbf{x}$ & 0 & 12 & 14 \\
\hline 8 & 5 & 0 & 0 & 11 & 12 & 0 & 1 & $\mathbf{x}$ & 11 & 13 \\
\hline 9 & 0 & 4 & 16 & 4 & 15 & 10 & 8 & 16 & $\mathbf{x}$ & 17 \\
\hline 10 & 0 & 9 & 4 & 15 & 3 & 10 & 4 & 17 & 0 & $\mathbf{x}$ \\
\hline
\end{tabular}

4. ábra Redukált mátrix (saját szerkesztés)

A minimalizált útvonal adott állomásának meghatározásához egy újabb redukált értéket szükséges meghatározni. Ez az érték abban különbözik az előzőtől, hogy minden szakaszhoz más érték tartozik. Például az $1 \rightarrow 2$ szakasz vizsgálatakor ki kell zárni az első sor és második oszlop összes elemét: ha a kiindulási állomás az „1” jelü, akkor az adott sor többi értéke elhanyagolható. Ugyanezen müködés alapján ha az érkezési állomás a „„” jelü, akkor az adott oszlop többi értéke szintén feleslegessé válik. Ezen felül a rövidre zárás miatt a $2 \rightarrow 1$ szakaszt szintén ki kell zárni. A kizárások után újra redukáljuk az adott mátrixot, ami ezen müveletek miatt más eredményt ad, mint az elsődleges redukált összegérték. 
Minden szakaszhoz egy költségértéket rendelünk, amely az alábbi képlet segítségével számítható ki:

$$
\operatorname{Cost}(x, y)=R(x, y)+\gamma+\hat{\gamma}(x, y)
$$

$\operatorname{Cost}(\boldsymbol{x}, \boldsymbol{y}):$, $\mathrm{x}$ ” és „,y” állomás közötti szakasz költségértéke

$\boldsymbol{R}(\boldsymbol{x}, \boldsymbol{y}):$, „x” és „,y” állomás közötti szakasz hossza

$\gamma$ : elsőrendü redukált mátrix értéke

$\widehat{\gamma}(x, y):$,X” és ,y” állomás közötti szakaszhoz tartozó másodrendü redukált mátrix értéke

A második állomás meghatározásakor a kiindulási „, állomás minden esetben az „1” jelü állomás lesz és az összes lehetséges eset megvizsgálásra kerül (5. ábra).

\begin{tabular}{|c|l|r|}
\hline \multicolumn{1}{|c|}{ A } & \multicolumn{1}{|c|}{ B } \\
\hline 2 & $\operatorname{Cost}(1,2)$ & 47 \\
\hline 3 & $\operatorname{Cost}(1,3)$ & 47 \\
\hline 4 & $\operatorname{Cost}(1,4)$ & 59 \\
\hline 5 & $\operatorname{Cost}(1,5)$ & 57 \\
\hline 6 & $\operatorname{Cost}(1,6)$ & 47 \\
\hline 7 & $\operatorname{Cost}(1,7)$ & 49 \\
\hline 8 & $\operatorname{Cost}(1,8)$ & 47 \\
\hline 9 & $\operatorname{Cost}(1,9)$ & 50 \\
\hline 10 & $\operatorname{Cost}(1,10)$ & 39 \\
\hline
\end{tabular}

5. ábra Költségérték vizsgálat a második állomás meghatározásához (saját szerkesztés)

Az optimalizált útvonal létrehozásához minden esetben az adott állomáshoz tartozó legkisebb költségértékủ szakaszt kell kiválasztani, így jelen esetben a második állomás a „10” jelü állomás lesz. Az előző folyamatok megismétlésével meghatározható a teljes optimalizált körjárat. Költségérték számításkor az adott szakasz folyamatosan változik, az elsőrendủ redukált mátrix értéke szakasztól független konstans érték. Másodrendủ redukált mátrix értékénél azonban a kizárásokra folyamatosan kell figyelni. A kiindulási pont teljes sorértéke, az érkezési pont teljes oszlopértékének kizárásán túl az előzőleg felhasznált állomásokhoz tartozó sor-, és oszlopértékeket is ki kell zárni. Például a harmadik állomás meghatározásakor ki kell zárni az „1” és „10” jelü állomások teljes sor,- és oszlopértékeit, ugyanis innen már nem indulhatnak ki és érkezhetnek ide szakaszok (kivéve az utolsó érték meghatározásakor az érkezési pont az „1” jelü állomás a körjárat feltétel miatt). A Branch \& Bound algoritmus által létrehozott körútvonal az 1. táblázat szerint meghatározható.

\begin{tabular}{|c|c|c|}
\hline Route & Cost $(\min )$ & $\mathrm{L}(\mathrm{min})$ \\
\hline $\mathbf{1}$ & & \\
\hline $\mathbf{1 0}$ & 39 & 1 \\
\hline $\mathbf{3}$ & 43 & 5 \\
\hline $\mathbf{2}$ & 45 & 6 \\
\hline $\mathbf{5}$ & 50 & 1 \\
\hline $\mathbf{7}$ & 54 & 3 \\
\hline $\mathbf{8}$ & 63 & 4 \\
\hline $\mathbf{6}$ & 78 & 8 \\
\hline $\mathbf{4}$ & 102 & 1 \\
\hline $\mathbf{9}$ & 122 & 11 \\
\hline $\mathbf{1}$ & & 3 \\
\hline
\end{tabular}

1.táblázat Az optimalizált körjárat útvonala (saját szerkesztés) 


\section{Eredmények összehasonlítása}

Az optimalizálás végeredményeként a Branch \& Bound algoritmus segítségével létrejött körutazás 43 útvonalegység alatt járható be. Azonban, ha ez a körutazás nem valósítható meg, akkor a célállomásokat ingajáratként egyenként kell bejárni, ami a lényegesen több utazás időszükséglete mellett a betárolás, illetve kitárolás időszükséglete is lényegesen nagyobb (6. ábra).
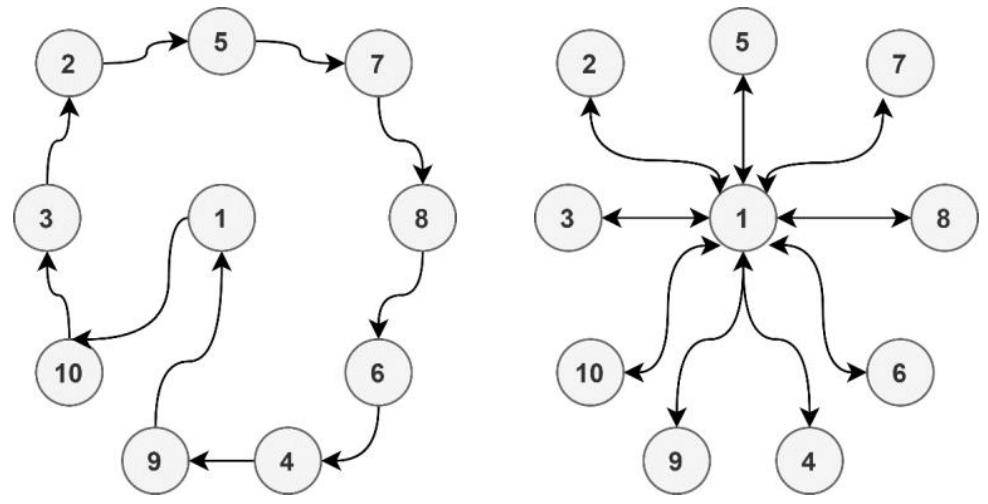

6. ábra. A létrejött körútvonal és az ingajárat (saját szerkesztés)

Az ingajárat útvonalhosszának meghatározásához a kiinduló útmátrix első állomásától az összes állomásig, valamint az összes állomástól az első állomásig tartó útszakaszokat kell összeadni:

$$
L_{\text {inga }}=\sum_{n=1}^{9} L(1, n)+\sum_{n=1}^{9} L(n, 1)=203
$$

A végeredményekből látható, hogy a körutazás útvonala közel negyedannyi, mint az egyenként történő bejárás útvonalához, ami jól rámutat arra, hogy milyen jelentőséggel bír az adott kutatási terület, és a jövőbeli fejlesztésekkel milyen út-, és hozzá kapcsolódó időmegtakarítások érhetőek el (7. ábra).

$$
L_{k o ̈ r u ́ t ~}=43 \quad L_{\text {inga }}=203
$$

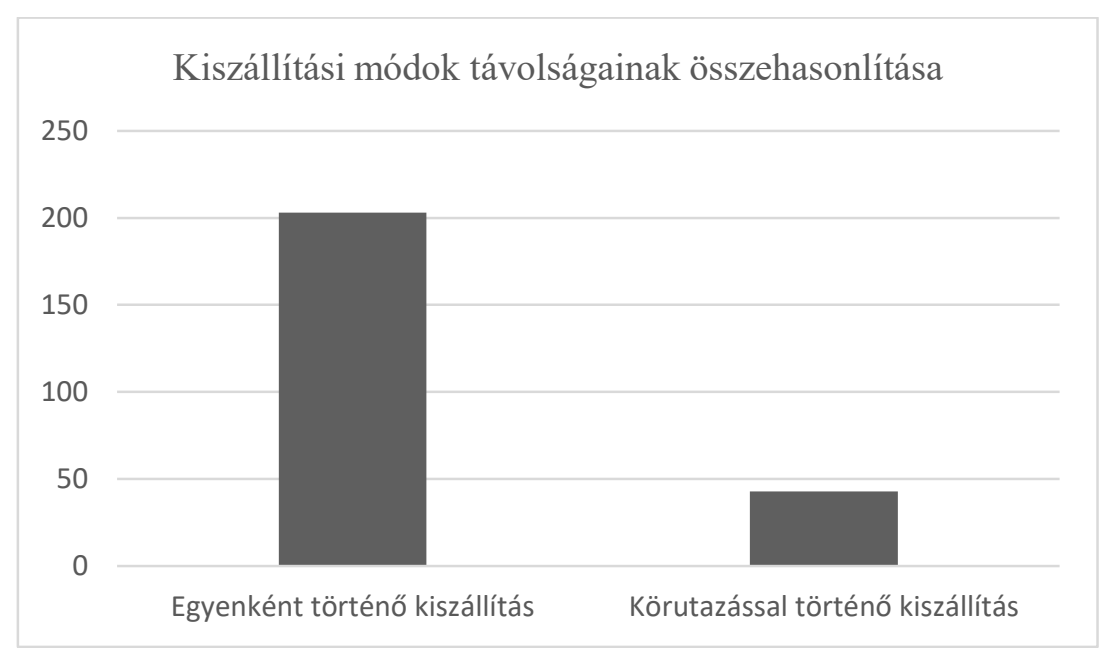

7. ábra. Kiszállitási módok távolságainak összehasonlitása (saját szerkesztés) 


\section{8. Összefoglalás}

A drónos anyagmozgatás napjainkban egyre nagyobb jelentőségre tesz szert, hiszen a technológia fejlődése és a szabályozás egyre kiforrottabbá válása egyre több területen teszi lehetővé a drónos szállítás gyakorlati megvalósítását. A drónos rendszerek kiépítése számos olyan tervezési feladat megvalósítását igényli, melyek olyan logisztikai feladatok újragondolását igénylik, mint például a járattervezés, ütemezés, erőforrások összerendelése. Jelen cikk keretében a szerzők a korlátozások és szétválasztások módszerén keresztül mutatnak be egy példát a drónok segítségével támogatott csomagszállítás tervezésére vonatkozóan. A bemutatott tervezési módszer alkalmazhatósága nem csupán tiszta drónos kiszolgálás esetében lehetséges, hanem olyan hibrid megoldásoknál is alkalmazható, ahol a drónos kiszolgálás kiegészít egy hagyományos szállítási ágazatot, például a tehergépkocsival történő csomagszállítás és a drónos kiszállítás kombinációjaként. Jövőbeli kutatási terveink között szerepel a módszer kiterjesztése többjáratos, idő- és kapacitáskorláttal rendelkező hibrid rendszerek vizsgálatára.

\section{Köszönetnyilvánítás}

A cikkben ismertetett kutató munka az EFOP-3.6.1-16-2016-00011 jelü „Fiatalodó és Megújuló Egyetem - Innovatív Tudásváros - a Miskolci Egyetem intelligens szakosodást szolgáló intézményi fejlesztése" projekt részeként - a Széchenyi 2020 keretében - az Európai Unió támogatásával, az Európai Szociális Alap társfinanszírozásával valósul meg.

„AZ INNOVÁCIÓS ÉS TECHNOLÓGIAI MINISZTÉRIUM ÚNKP-21-1. KÓDSZÁMÚ ÚJ NEMZETI KIVÁLÓSÁG PROGRAMJÁNAK A NEMZETIKUTATÁSI, FEJLESZTÉSI ÉS INNOVÁCIÓS ALAPBÓL FINANSZÍROZOTT SZAKMAI TÁMOGATÁSÁVAL KÉSZÜLT.”
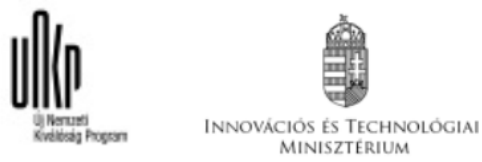

\section{Irodalom}

[1] Walker Sands Future of Retail 2016 Study

Elérhetö: https://www.walkersands.com/resources/the-future-of-retail-2016/ Letöltve: 2021.09.11.

[2] Delivery Drones are Taking Off!

Elérhető: https://supplychaingamechanger.com/delivery-drones-are-taking-off-infographic/ Letöltve: 2021.07.08

[3] Energy use and life cycle greenhouse gas emissions of drones for commercial package delivery Elérhetö: https://www.nature.com/articles/s41467-017-02411-5_Letöltve: 2021.09.11.

[4] Salama, M., Srinivas, S. (2020) Joint optimization of customer location clustering and drone-based routing for last-mile deliveries. Transportation Research Part C: Emerging Technologies, 114, 620-642. https://doi.org/10.1016/j.trc.2020.01.019

[5] Moshref-Javadi, M., Winkenbach, M. (2021) Applications and Research avenues for drone-based models in logistics: A classification and review. Expert Systems with Applications, 177, 114854. https://doi.org/10.1016/j.eswa.2021

[6] Agárdi, A., Kovács, L., Bányai, T. (2019) Vehicle routing in drone-based package delivery services Solutions for Sustainable Development - Proceedings of the 1st International Conference on Engineering Solutions for Sustainable Development, 2019, pp. 151-159. https://doi.org/10.1201/9780367824037-20 
[7] Almuhaideb, S., Alhussan, T., Alamri, S., Altwaijry, Y., Aljarbou, L., Alrayes, H. (2021) Optimization of truck-drone parcel delivery using metaheuristics. Applied Sciences (Switzerland), 11(14), 6443. https://doi.org/10.3390/app11146443

[8] Yadav, V., Narasimhamurthy, A. (2018) A heuristics based approach for optimizing delivery schedule of an Unmanned Aerial Vehicle (Drone) based delivery system. 9th International Conference on Advances in Pattern Recognition, pp. 398-403. https://doi.org/ 10.1109/ICAPR.2017 